\title{
Porijeklo teorije umjetnosti u kritici disciplinarne institucije povijesti umjetnosti
}

Briski Uzelac, Sonja

Source / Izvornik: Institucije povijesti umjetnosti : zbornik 4. kongresa hrvatskih povjesničara umjetnosti, 2019, 173 - 179

Conference paper / Rad u zborniku

Publication status / Verzija rada: Published version / Objavljena verzija rada (izdavačev PDF)

https://doi.org/10.31664/z4khpu.24

Permanent link / Trajna poveznica: https://urn.nsk.hr/urn:nbn:hr:254:828979

Rights / Prava: Attribution 4.0 International/Imenovanje 4.0 međunarodna

Download date / Datum preuzimanja: 2023-04-26

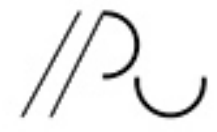

INSIITUTR ZA POVIJEST UMJETNOST
Repository / Repozitorij:

PODEST - Institute of Art History Repository

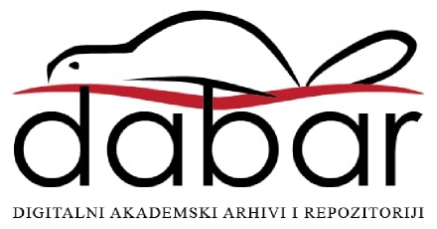




\section{Porijeklo teorije umjetnosti u kritici disciplinarne institucije povijesti umjetnosti}

Sve dok umjetnost nije bila dovedena u pitanje, trebalo je samo ispričati njezinu povijest, hvaliti njezine dosege ili kritizirati dekadenciju. ${ }^{1}$ - Hans Belting, Kraj povijesti umjetnosti?

Navedene riječi Hansa Beltinga, autora knjige koja problematizira tezu o kraju povijesti umjetnosti, daju konceptualne okvire tezi u ovoj raspravi. U lociranju danas prisutne teze o teoriji umjetnosti kao transdisciplinarnoj kritičkoj intervenciji u disciplinarnu instituciju povijesti umjetnosti ne polazi se od povijesne, već od suvremene situacije u kojoj se našla umjetnost sama, kao i njezina interpretacija. O značenju i značaju tog „obratnog” pristupa govori i činjenica da je „izučavanje suvremene umjetnosti postalo tematsko područje s najvećim rastom u akademskom svijetu od početka stoljeća". ${ }^{2}$ Kada se, dalje, usporede disciplinarni diskursi unutar toga područja, posve se jasno očituje prevladavanje teorijskog nad povijesnoumjetničkim ili kritičarskim diskursima. Već u ranim I970-im godinama suvremena je umjetnost ostvarila istaknuto mjesto i u muzejsko-galerijskom sustavu, što potvrđuje izrazit porast osnivanja velikoga broja muzeja suvremene umjetnosti, kao i posljedično nagao razvoj kustoskih praksi i platformi. Razlog tako vidljivu ugledu suvremene umjetnosti jest i u naglom razvoju novoga pristupa suvremenosti, tvrdi Terry Smith (2009.) u svom teorijskom razmatranju razlika koncepata modernosti, postmodernosti i suvremenosti. ${ }^{3}$

Status umjetnosti u suvremenome razdoblju oslanja se na sam koncept kulturne suvremenosti, koji se više ne razvija kao jednosmjerni projekt modernosti ili pak njegovo rušenje, već u smjeru danas već sveprisutne kaotične globalnosti, pa tako i globalnosti umjetnosti. Koncept suvremenosti zapravo je „postkolonijalni” koncept, to jest on se prvenstveno „vodi namjerom da zamjeni shemu centra i periferije hegemone modernosti i da potvrdi slobodu od privilegija povijesti", kako je to formulirao Hans Belting. ${ }^{4}$ U knjizi After the End of Art (I997.), autor

\section{Sonja Briski Uzelac}

redovita profesorica u miru sonja.briski@gmail.com

https://orcid.org/oooo-ooo3-1642-6519
I HANS BELTING, Kraj povijesti umjetnosti?, Zagreb, 20I0., 273 .

2 CLAIRE BISHOP, Radical Museology or, What's 'Contemporary' in Museums of Contemporary Art?, London, Koenig Books, 20I3., I6.

3 TERRY SMITH, What is Contemporary Art?, Chicago, University of Chicago Press, 20og. (prijevod: TERI SMIT, Savremena umetnost i savremenost, Beograd, Orion Art, 20I4.).

4 HANS BELTing, From World Art to Global Art: View on a New Panorama, u: The Global Contemporary and the Rise of New Art Worlds, (ur.) Hans Belting, Andrea Buddensieg, Peter Weibel, Cambridge, MIT Press; Karlsruhe, ZKM, 20I3., I78.

5 ARTHUR C. DANTO, After the End of Art. Contemporary Art and the Pale of History, Princeton, Princeton University Press, I997., I3. 
Arthur C. Danto ne samo da je konstatirao činjenicu o svakoj "odsutnosti razvojnog pravca”, nego je ustvrdio da je to „odredbena crta novog razdoblja”. To je „razdoblje nevjerojatne eksperimentalne produktivnosti u vizualnim umjetnostima bez jednosmjernog narativnog pravca, odredbena crta novog razdoblja". ${ }^{5}$

Može se reći, i bez pozivanja na povijesne ili neoavangardne pokrete, modernizam (rani, visoki, kasni) ili epizodu postmodernizma, da smo suočeni sa suvremenom „posthistorijskom” situacijom ili „gubitkom” povijesti u smislu linearnog „razvojnog konteksta" (Danto). Dakle, umjetnost sada zadobiva „dokumentarni" karakter kulturne činjenice suvremenosti, a to je obilježje koje uspješno odgovara svome referentu. Postoji beskonačni broj načina produkcije umjetnosti čiji se različiti segmenti slobodno povezuju u referentnu mrežu koja jest globalna suvremenost sama (medijska i druga diseminacija, muzejska i galerijska prezentacija, kustoske platforme, bijenalne i druge manifestacije, ambijentalni i aktivistički događaji u javnom prostoru...). U fokus umjetničke prakse ulaze i različiti oblici djelovanja, među njima novi aspekti arhiviranja suvremenosti neodvojive od prošlosti, od osobnih i privatnih do širih javnih, političkih, socijalnih, ekonomskih ili povijesnih okvira, što pokazuje kako paradigma modernosti prelazi u radikalnu paradigmu suvremenosti: svojim različitim kon/ tekstualnim dispozitivima rekonfiguriraju i pristup umjetnosti samoj. Taj pristup raspolaže prednostima interaktivnog medija elektronske tehnologije, čime je polje čitljivosti otvoreno iako je pogled dislociran: svi objekti, u svako vrijeme i na svakom mjestu, mogu biti viđeni zajedno u istom prostoru znanja što formatira distribuciju prostora (inter)aktivnog društvenog pamćenja, a ne sustav reprezentacije.

Suvremenost samu karakterizira njezina singularna sadašnjost $\mathrm{u}$ hegemoniji trenutka nad vremenom, odnosno suvremenost se sastoji, kako kaže istraživač statusa suvremene umjetnosti u suvremenosti Terry Smith, od „ubrzanja, sveprisutnosti i konstantnosti radikalnih raskida percepcije, neusklađenosti načina gledanja i procenjivanja istog sveta, u aktuelnoj koincidenciji asinhronih vremenitosti, u upornoj kontingenciji raznih kulturalnih i društvenih mnoštvenosti koje su okupljene tako da potcrtavaju narastajuće nejednakosti u njima i među njima" (naglasio Smith). ${ }^{6}$ U toj situaciji neprestana prelaženja i prevođenja iz mogućnosti (potencijalnosti) u čin (stvarnost), uz koincidenciju vremenske asinkronije i kontingencije mnoštva, sama je umjetnost, paradoksalno, globalno lokalizirana. To znači ne samo da je umjetnost prisutna na beskonačan broj načina nego se ona kao globalni fenomen zaista uspostavlja na bezbroj načina u točkama povezanosti: javni umjetnički ili neumjetnički prostori su lokacije, stvarne ili virtualne, kao mjesta mnogostrukih događajnosti. No sama lokalizacija umjetničkog događaja ostvaruje globalnu i lokalnu povezanost po srodnosti, kako s pojedinim središtem, tako i s određenim sredinama: suvremena je umjetnost lišena određenja odnosom periferija - centar kao i drugih posebnih ograničenja (nacionalne, regionalne ili druge granice), jer svaku
6 TERI SMIT [TERRY SMITH] (bilj. 3, 20I4.), 26. 
lokalizaciju čini vidljivom upravo suvremena dominantnost stanja globalizacije.

Status umjetnosti unutar novih pojmovnih rekonfiguracija i kulturnih resemantizacija, dakle, doživio je niz obrata, čemu bitno svjedoči i njezina najnovija transfiguracija u umjetnost u doba globalne kulture suvremenosti. Na djelu je rekonstituiranje funkcije umjetnosti kojom ona ponovno, a nakon modernističke ideologije formalne autonomije umjetnosti, postaje „stvar kulture" s određenim društvenim funkcijama posredovanja. To je proces transfiguracije umjetnosti u događajnost nove označiteljske prakse kulturnih zahtjeva i društvenih očekivanja kojim postaje vidljiv sam način „vizualne konstrukcije kulture”. Suvremeni paradoks koji u suočenju sa sve većom kulturnom diferencijacijom razapinje vizualnu umjetnost između lokaliziranosti prostora i povijesnosti vremena, određuje bitno i status njezine interpretacije. Određivanje tog statusa može se podržati teorijskim tezama koje je strukturirao Terry Smith trima pojmovima, a to su: stvaranje mjesta (placemaking), prikazivanje svijeta (world picturing) i povezivanje (connectivity). ${ }^{7}$

A kakve odgovore danas, u 2I. stoljeću, na ta pitanja može ponuditi akademska disciplina povijesti umjetnosti, a da ti odgovori nisu „zakašnjeli”, poput onih, primjerice, u vezi s djelovanjem Marcela Duchampa u prvoj ili Jeffa Walla u drugoj polovini 2o. stoljeća? $\mathrm{U}$ međuvremenu je suvremena umjetnost postala institucionalno polje i objekt propitivanja i istraživanja u akademskom području, ali kao objekt već premrežen istraživačkim opcijama vizualne kulture ili diskurzivnim vizurama teorije umjetnosti. Poznato je da se normativna povijest umjetnosti zasniva na čvrsto uspostavljenoj instituciji autora i djela. Suvremenim kulturnim raslojavanjima predodžbe o djelu razgrađuje se samo autorsko djelo, a raste energija njegove tekstualne (značenjske) potencije zajedno s iniciranjem događanja u kojemu je vrijeme (pamćenje) aktivni činilac. „Djela” se sad pojavljuju i istražuju kao „dokumenti” na osnovi kojih se „čita” upisano značenje nekog već prošlog umjetničkog čina kao aktualnog kulturalnog teksta. To značenje nije fiksirano, ni definitivno, ono ovisi od načina čitanja, odnosno interpretiranja neovisno iz kojeg teorijskog okruženja dolazi, pa se može reći da hermeneutički pristup postaje os oko koje se organiziraju drugi pristupi.

Uglavnom, to polje istraživanja odvija se pod plaštom interdisciplinarnosti (komparativni i kulturalni studiji, vizualni studiji), intermedijalnosti (na umjetničkim institucijama) ili transdisciplinarnosti kritičke teorije umjetnosti. Gotovo da je kao contradictio in adjecto, naznačen „nelagodni zaključak” u često citiranu časopisu October (br. I3o, jesen 20og.): u upitniku koji tematizira odnos suvremene umjetnosti i povijesti suvremene umjetnosti iznesena je konstatacija o „novom osjećaju”, koji govori da je „u samoj svojoj heterogenosti dobar dio sadašnje prakse naizgled oslobođen od povijesnih određenja, konceptualne definicije i kritičkog prosuđivanja". ${ }^{8}$ Radi se, dakle, o drukčijem životu umjetnosti, čije suvremene manifestacije izmiču postojećem kritičkom aparatu i predmetnom određenju struke povijesti umjetnosti jer remete njezinu disciplinarnu sklonost deskripciji, tipologiji, retrospekciji ili procjenjivanju
7 TERI SMIT [TERRY SMITH] (bilj. 2, 20I4.), I6.

8 A Questionnaire on „The Contemporary”, u: October, I30 (2009.), 3-I24. 
vrijednosti. Slijedom argumentacije možemo se osloniti na kratki opis „ustanka umjetnosti protiv povijesti umjetnosti” koji daje Hans Belting: „Tematika visokog i niskog ne jenjava, određujući smisao umjetnosti u otvorenom dijalogu sa svijetom svakodnevice. U tome je sadržan i poticaj protiv diktata povijesti umjetnosti. Klasična je moderna još željela stvarati povijest umjetnosti, što znači pravocrtno je odvesti u budućnost. Poslijeratna je umjetnost naprotiv nastojala sići s posebnog puta povijesti umjetnosti i uklopiti se u povijest svojega doba. Što god da je pritom nastalo, u ovom slučaju ponovno nova umjetnost za prodaju, ne mijenja ništa u namjeri. Stil koji su umjetnici prihvatili bio je takoreći stil svakodnevice (i medija), pa je time prekinuo unutarnju logiku povijesti umjetnosti, barem onu koja je vrijedila do tada."

Konstatacija, dakle, o umjetnosti kao „takoreći stilu svakodnevnice (i medija)”, koji se uklapa „u povijest svoga doba” odnosi se zapravo na kontekstualno rekonstituiranje uloge umjetnosti kada ona uključuje aktivističku razinu kulturnih praksi oblikovanja i zastupanja u svakodnevnom životu. Pritom je riječ o jedinstvenim, posebnim i potencijalno beskonačno značenjski razlikovnim kulturnim kontekstima i njihovim institucionalizacijama. Otuda, sa stajališta metodološkog pristupa, u prvi plan takva sagledavanja suvremene umjetnosti stupa kontekst „društvene definicije kulture” kao njezina implicitna podloga. Ta je relacija zasnovana, suglasno kulturalnoj teoriji Raymonda Williamsa (I984.), ${ }^{10}$ na analizi označavanja i razjašnjavanju značenja i vrijednosti koje su podrazumijevane određenim načinom života. No umjetnička praksa koja povezuje koncepte kulture i koncepte značenja po svojoj je prirodi hibridna i predočava se kao mreža značenja. Kao takva ona je neuhvatljiva za pristupe onih medijskih, stilskih, formalnih i inih hijerarhija modernizma kojima se bavila likovna kritika ili se mogla disciplinarno baviti povijest umjetnosti.

Kada „umjetničko djelo” kao završeni „artefakt” bude očigledno zamijenjeno prezentacijom otvorenih i vidljivih interventnih i interaktivnih umjetničkih praksi u specifičnim kontekstualnim odnosima, onda u „prepoznavanju umjetnosti” nisu od pomoći „čiste” disciplinarne metode. Mnogostruke relacije singularnosti i univerzalnosti, kao i mnoštvo i višestrukost identiteta i otpora kao nove paradigme u umjetničkom djelovanju, traže i nove inter/transdisciplinarne načine razumijevanja i interpretacije. Tako se oblikovala nova strategija teorijske prakse u izučavanju suvremene umjetnosti, a koja se oslanjala na hibridne diskurse kulturalne analize. Ta hibridnost ide $u$ dva smjera: prema hibridnosti predmeta izučavanja (novi status suvremene umjetnosti) i prema hibridnosti teorija izučavanja, odnosno diskursa teorijske analize (kritički status teorije umjetnosti).

Ako se fokusiramo na diskurse teorijske analize koji su se razvili iz kuta gledanja kulturalne analize, treba reći kako ti diskursi naglašavaju da ovo „novo znanje” u proizvodnji intertekstualnog teorijskog tumačenja o suvremenoj umjetničkoj praksi nikako nije neutralno ili objektivno, a u smislu kako na „stručno znanje" pretendira institucija povijesti umjetnosti. Status tog,
9 HANS BELTING (bilj. I), I23.

Io RAYMOND WILLIAMS, Writing and Society, London, Verso, I984. 
novog znanja jest kritički, odnosno tekstualni jer usmjerava na „čitanje teksta” kao ishoda procesa označavanja. Samo znanje je učinak pozicioniranosti (interpretacije), ili, fukoovski rečeno, to je učinak mjesta s kojeg netko govori, komu govori i iz kojih razloga govori. Taj status korespondira s neoliberalnim globalizmom u kojemu je i došlo do bitnih promjena $u$ stvaralačkom (poetičkom), medijskom (produkcijskom), organizacijskom (kustoskom), komunikacijskom (distribucijskom, izložbenom ili promotivnom) kao i ekonomsko-financijskom karakteru umjetničke prakse i njezina položaja unutar institucija kulture i društva. Stoga je teorija umjetnosti stanovit oblik diskurzivne formacije (Michel Foucault, Stuart Hall), koja ima svoje koncepte i prakse koji stvaraju pristupe govoru o procedurama izvođenja znanja i upravljanja znanjem unutar institucionalnih pozicija (primjerice, znanosti ili galerija i muzeja) kao i društvenih i kulturnih aktivnosti (primjerice, aktivističke prakse, arhivi, urbani prostor, i sl.).

Nova situacija tražila je novu paradigmu koja je u najvećoj mogućoj mjeri mogla osigurati adekvatne alate za novi model interpretacije: studij kulture (teorijske pretpostavke birmingemskog kruga britanske intelektualne scene oko Stuarta Halla) i kulturalna analiza (metodologija), pojavljuju se kao prihvatljiva početna kritička platforma za razvoj strategije proučavanja ne samo elitne visoke kulture nego i za mnoštva heterogenih pozicija u kulturi koje u sebi nose koncepte „mikrootpora”. Kulturalna je analiza nakon lingvističkog obrata 20. stoljeća svojim pristupom čitanja kulturalnih tekstova odnosno značenja kulturalnih praksi, stavila u prvi plan pojam razlike umjesto dominacije „kulturnih fenomena” ili kanoniziranih „remekdjela”. Razlika isključuje fiksirane oblike binarnog kodiranja (priroda/kultura, muškarac/žena, razum/ludilo, zapad/istok, i dr.) i traži modalitete uključene u prostore između supostavljenih i suprotstavljenih kodova. Kapilarno prodiranje u ove odnose, encoding-decoding (Hall), pridonosi konstituiranju suvremenih platformi za teoriju vizualnih umjetnosti. Njezino se porijeklo može tumačiti nizom pojedinačnih određenja kojima se postavljaju pokazni odnosi iz kulturne i umjetničke prakse (feminističke ili postkolonijalne platforme, muške antropologije, „skopički režimi”, „arheologije” slike, estetike traga i života, i dr.), kao i iz konstelacije kontekstualnog polja. U tom polju prvenstveno dominiraju odnosi oblika moći i kulture (jer „u kulturi ništa nije nedužno”), pa je i predmet istraživanja usmjeren na prepoznavanje artikulacija umjetničkih koncepata i oblika aktualnosti koji otvaraju poglede na relativne i relacijske pravce čitanja. Iako novo institucionalno mjesto za prakticiranje kritičkoga teorijsko-umjetničkog diskursa postaje akademska mreža, taj diskurs zbog svoje disciplinarne nestrukturiranosti postaje otvorenim mjestom kritičkog propitivanja; s obzirom na to, podsjeća nas Terry Smith, kako se pune „odlagališta otpada modernosti”, tako su i suvremene prakse medijskog globalnog neoliberalizma „podjednako [...] podložne entropiji". ${ }^{11}$

Danas je potreban drukčiji održivi teorijsko-povijesni okvir za pristup suvremenoj umjetničkoj praksi, okvir koji uključuje
I TERI SMIT [TERRY SMITH] (bilj. 3, 20I4.), 39 .

I2 PETER osborne, Art Beyond Aesthetics: Philosophical Criticism, Art History and Contemporary Art, $\mathrm{u}$ : Art History, 27/4 (2004.), 666-667. 
različite interpretativne sklopove koji mogu obuhvatiti svu njezinu aktualnu raznolikost i heterokroniju, mnoštvene temporalnosti i lokacije. Tako Peter Osborne smatra da oni moraju artikulirati „kvalitativnu povijesnu novinu sadašnjosti” (2004.), ${ }^{12}$ premda se, u modernističkoj maniri, ne suočava u cijelosti, poput mnogih drugih, s onim što suvremenost sada zahtijeva od svojih umjetnika, ali i interpretatora. Naravno, postoji mnoštvo stajališta i viđenja, od akademskih rasprava do različitih i suprotstavljenih kustoskih platformi, kao i mnoštvo antologija interpretativnih eseja teoretičara, kritičara i kustosa (izdavački model Blackwell ili Taschen), obrada mnogih tema (mjesto, znak, tijelo, identitet...) ili označavanja "kritičkih pojmova” (Robert S. Nelson i Richard Shiff, r996.), ${ }^{13}$ i drugo. Prisutni manjak uporišne točke nastojao se doduše ispuniti u pristupu „nove povijesti umjetnosti" (New History of Art); ona je također na zasadama kulturalne analize ukazivala na „multizastupnički” koncept diskursa kao diskurs koji, a prema riječima teoretičarke kulture Mieke Bal, „primjenjuje skup semiotičkih i epistemoloških stavova koji omogućavaju i predodređuju načine komuniciranja i mišljenja, a koje svi oni koji sudjeluju u diskursu mogu koristiti, odnosno razumjeti". ${ }^{4}$ Takvu pristupu pridružuje se i Norman Bryson svojom kritičkom problematizacijom statusa same discipline povijesti umjetnosti, koja se, prema njegovim riječima, ne upušta u pitanja izvan svog „stručnog” djelokruga istraživanja, kao primjerice: Što je slika? Kakav je odnos između slike i percepcije? Kakav je odnos prema društvenoj moći? ${ }^{15}$ Stoga su, smatra on, naglašavanje „općeg humanizma” ili „vječnih i univerzalnih vrijednosti" samo izraz i učinak određenih stavova i prikrivenih pozicija unutar složenih društvenih kontradikcija i institucionalnih strukturacija.

Kognitivno mapiranje problema unutar teorijsko-kritičke metaanalize statusa same discipline povijesti umjetnosti, ali i statusa „imanentnosti umjetničkog djela”, zorno se pokazalo na djelu u kustoskim platformama velikih projekata, odnosno programa megaizložbi s kraja prošlog i početka ovog stoljeća. Tada su teoretičari, kustosi i umjetnici pokrenuli „veliku obrazovnu misiju” koja je uključila „glas, gledišta i umetnost isključenih drugih", ${ }^{16}$ a koja je kulminirala 2002. godine na Documenti II. $\mathrm{Na}$ čelu te misije u to vrijeme bio je Okwui Enwezor, glavni izbornik cjelovite izložbene manifestacije u Kasselu. On je sažeo svoju platformu u teorijsko-kritički stav kao znak stanja „postkolonijalne konstelacije”, koje se ne da obuhvatiti pristupima i tradicijom struke povijesti umjetnosti. ${ }^{17}$ Kategorije kao univerzalnost i autentičnost vrijednosti umjetničkog djela, autonomija umjetnosti i formalistička centriranost, imanentna estetska ili umjetnička logika razvoja umjetničkog djela i institucionalnog svijeta umjetnosti, samo su složeni „prividi” kojima tradicija zapadne misli situira i projicira idealno stanje umjetnosti. Ono je izdvojeno iz sfere društvenih konflikata i kulturnog konteksta različitosti, kako bi se ideološki predočilo vlastito idealno stanje, stanje „transcendentalnog pogleda”.

Dekonstrukcija tog pristupa prividne neutralnosti pogleda $u$ stručnom jeziku povijesti umjetnosti, kao i ostalih hijerarhijskih metajezika (drugih znanstvenih, filozofskih, estetičkih),
I3 Critical Terms for Art History, (ur.) Robert S. Nelson, Richard Shiff, Chicago, London, University of Chicago Press, I996. (2. izdanje 2003.).

I4 MIEKE BAL, Double Exposures: The Subject of Cultural Analysis, New York, Routledge, I996., 3.

I5 NORMAN BRYSON, Vision and Painting. The Logic of the Gaze, New Haven, London, Yale University Press, I983.

I6 TERI SMIT [TERRY SMITH] (bilj. 3, 20I4.), 59.

I7 OKWUi ENWEzor, The Black Box, u: Documenta II-Platform 5: Exhibition Catalogue, Ostfildern-Ruit, Hatje Cantz Publishers, 2002. 
neposredno je vodila hibridizaciji diskursa o umjetnosti; dakle ukratko, od povijesnoumjetničkog fokusiranog i sustavnog tumačenja „umjetničkog djela” do teorijskoga hibridnog tumačenja „konteksta umjetničkog djelovanja”. To nije značilo biti izvan matične kompetencije (Enwezor je inače po osnovnom akademskom obrazovanju sociolog), već biti u „vanjskom prostoru” (Michel Foucault), biti „između” ili, pak, u „trećem prostoru” kulturalne "translacije” (Homi Bhabha). To znači nemati jedno „drvo znanja”, jedno disciplinarno porijeklo znanja, pisati jednu povijest umjetnosti. Pisati teoriju umjetnosti znači pokazati spremnost za događaje prepoznavanja i kritičku intervenciju u suočavanju s konceptom razlike u zatečenom ili pak otkrivenom kontekstu. Tako i sama teorija predstavlja događaj poput agensa, pokretne sile ili spoja elemenata koji djeluje u tom procesu. Kao djelotvorno sredstvo u tumačenju, teorija preuzima na sebe postavljanje kategorija, metoda i predmeta u takvu relaciju da ta relacija može preuzeti na sebe pojmove i procedure interpretacije druge discipline (antropologije, etnologije, sociologije, filozofije, i dr.), a da pritom ostane vrlo bliska samu objektu propitivanja i istraživanja. Nije u pitanju neka sistemska teorija umjetnosti, već posve otvoren sustav, gotovo poput mreže polemičkog suočavanja iz različitih diskurzivnih perspektiva i točaka susreta s praksama umjetnosti i kulture. Suočavanje problematizira i preispituje različite odnose institucionalnih dominacija: centar/periferija, hegemono/marginalno, vertikalno/horizontalno, linearno/ višestruko, jedinstveno/hibridno, autentično/referentno, čisto/ eklektično, racionalno/skriveno, prezentacija/reprezentacija, tjelesno/vizualno, optičko nesvjesno/političko nesvjesno, univerzalno/singularno, samozaborav/sjećanje, i dr. Da parafraziramo Fredrica Jamesona, događaji mogu obnoviti svoju prvobitnu urgentnost za nas samo ako se ponovo ispričaju unutar cjeline priče, iako su u prerušenoj i simboličkoj formi i okruženi frojdovskim potiskivanjem, sažimanjem i premještanjem. ${ }^{18}$ Tako se pitanje o umjetnosti i povijesti postavlja kao pitanje o kulturnome, a ne povijesnoumjetničkome, o značenju umjetnosti unutar njezina vremena trajanja.

Otvorenost pristupa prema silini novih pitanja zahtijeva otvorenost prema traženju odgovora: s koje ćemo platforme protumačiti neko umjetničko djelovanje i modalitete pripadnih mu subjektivnosti i kulturalnosti ovisi ne samo o stanju suvremene posttranzicijske interpretativne konstelacije nego i o lokacijama kao mjestima pristupa mreži značenja i postupku dešifriranja posebnosti njihovih simboličkih „diskurzivnih formacija” unutar diskontinuiteta između suvremene i starije umjetničke prakse.

\section{() (1)}

Porijeklo teorije umjetnosti u kritici disciplinarne institucije povijesti umjetnosti / Sonja Briski Uzelac/ CC BY / 4.0

DOI: https://doi.org/ıo.3I664/z4khpu.24
I8 FREDERIC JAMESON, The Political Unconscious: Narrative as Socially Symbolic Act, Ithaca, Cornell University Press, I98I., I9-20. 